\title{
Multiple cis-acting signals for export of pre-U1 snRNA from the nucleus
}

\author{
Michael P. Terns, James E. Dahlberg, ${ }^{1}$ and Elsebet Lund \\ Department of Biomolecular Chemistry, University of Wisconsin, Madison, Wisconsin 53706 USA
}

\begin{abstract}
We have identified cis-acting sequences that promote nuclear export of pre-U1 RNA injected into Xenopus oocyte nuclei. At least three elements, the $5^{\prime} \mathrm{m}^{7} \mathrm{G}$ cap, the $3^{\prime}$-terminal stem-loop structure, and sequences in the 5'-terminal 124 nucleotides, contribute to efficient export of this RNA. Both the 5' and 3' export signals can function separately and do so independently of the cap structure. Experiments using hybrid RNAs indicate that the $5^{\prime}$ and $3^{\prime}$ export sequences of U1 RNA are sufficient to direct export of the heterologous, otherwise nonexportable, U6 RNA. The absence of comparable export signals in U6 RNA appears to be responsible for its retention in the nucleus. Stability of the pre-snRNAs in the nucleus depends on the presence of both a $5^{\prime}$ cap structure and a $3^{\prime}$ base-paired stem. The $5^{\prime} \mathrm{m}^{7} \mathrm{G}$ cap is neither sufficient nor necessary for nuclear export. The $\mathrm{m}^{7} \mathrm{G}$ cap by itself did not promote export of U6 RNA or nonspecific small RNAs. Moreover, substitution of this cap with either an ApppG cap or $\gamma$-mpppG cap did not eliminate export of either full-length or a "minimal" U1 RNA (lacking most of the internal U1 RNA sequences), but it reduced the rate of export by about two to threefold. However, in the absence of the $3^{\prime}$ stem-loop, substitution of the $\mathbf{m}^{7} \mathrm{G}$ cap led to a greater decrease in export rate, underscoring the cooperative action of the three different export elements of pre-U1 RNA. The $\mathrm{m}^{7} \mathrm{G}$ cap analog, $\mathrm{m}^{7} \mathrm{GpppG}$, selectively destabilized pre-U1 RNA within the nucleus. Thus, nuclear components that recognize the $5^{\prime} \mathrm{m}^{7} \mathrm{G}$ cap may be important for both the stability and the export of pre-U1 RNA.
\end{abstract}

[Key Words: Export; RNA; U1 snRNA; nucleus; nucleo-cytoplasmic transport, Xenopus oocyte]

Received June 9, 1993; revised version accepted August 11, 1993.

Export of RNA from the nucleus to the cytoplasm is a highly selective, energy-requiring process that depends on specific cis-acting signals within the structure of the RNAs (Zasloff 1983; Guddat et al. 1990; Hamm and Mattaj 1990; Eckner et al. 1991; Dargemont and Kühn 1992; Sun et al. 1992; for review, see Maquat 1991; Izaurralde and Mattaj 1992). The transport of RNA through the large nuclear pore complexes (NPCs) (Dworetzky and Feldherr 1988; Mehlin et al. 1992) can be inhibited by general inhibitors of nuclear pore function, such as wheat germ agglutinin and anti-pore protein antibodies (Featherstone et al. 1988; Bataille et al. 1990; Neuman de Vegvar and Dahlberg 1990; Dargemont and Kühn 1992; Michaud and Goldfarb 1992; for review, see Nigg et al. 1991; Forbes 1992).

The U small nuclear RNAs, (snRNAs), which function in the processing of mRNAs and rRNAs (for review, see Steitz et al. 1988; Lührmann et al. 1990; Green 1991), offer unique model systems for studying the control of nuclear trafficking. This is because most snRNAs undergo bidirectional transport across the nuclear membrane, as they mature from precursor to functional forms.

${ }^{1}$ Corresponding author.
Soon after synthesis by RNA polymerase II (RNAP II) (Dahlberg and Lund 1988), precursor U1 RNA is exported from the nucleus to the cytoplasm, where the $5^{\prime} \mathrm{m}^{7} \mathrm{G}$ cap is hypermethylated, the $3^{\prime}$ end is partially shortened, and the RNA binds Sm proteins, common to many small nuclear ribonucleoprotein particles (snRNPs) (Parry et al. 1989; Lührmann et al. 1990). The assembled U1 snRNPs are then imported into the nucleus, where the final 3'end maturation occurs (Yang et al. 1992). U1-specific proteins (called $\mathrm{A}, \mathrm{C}$, and $70 \mathrm{~K}$ ) are also components of the functional nuclear U1 snRNP, but it is unclear where in the cell and when in the life cycle of the RNA these proteins associate with the U1 snRNA/Feeney and Zieve 1990; Jantsch and Gall 1992; Kambach and Mattaj 1992; Terns et al. 1993/. Import of U1 snRNPs depends on several structural features of U1 RNA, including the Sm protein-binding site, a $5^{\prime}$ trimethylated cap structure, and a proper $3^{\prime}$-end structure (Hamm et al. 1987, 1990; Fischer and Lührmann 1990; Neuman de Vegvar and Dahlberg 1990; Fischer et al. 1991, 1993; Michaud and Goldfarb 1992; this paper).

In contrast to U1 RNA, U6 snRNA remains in the nucleus (Hamm and Mattaj 1989; this paper). Soon after synthesis by RNAP III (Dahlberg and Lund 1988; Reddy and Singh 1992), the $5^{\prime}$ pppG of U6 RNA is converted 
into a $\gamma$-mpppG cap (Singh et al. 1990) and the $3^{\prime}$ end is elongated by nontemplated addition of uridylates (Reddy et al. 1987; Lund and Dahlberg 1992; Tazi et al. 1993) to which the nuclear protein La binds (Rinke and Steitz 1985; Reddy et al. 1987; Terns et al. 1992). Fully mature U6 RNA contains a 2 ', 3 '-cyclic phosphate 3 '-end group (Lund and Dahlberg 1992) and does not bind the La protein (Terns et al. 1992). When U6 RNA is injected into the cytoplasm of Xenopus laevis oocytes, it is imported into the nucleus by a mechanism that depends on a single-stranded region in the RNA (Hamm and Mattaj 1989).

The mechanisms responsible for the selective and efficient export of pre-U1 RNA remain unclear. Export of pre-Ul snRNA is not strictly coupled to synthesis (Neuman de Vegvar and Dahlberg 1990), because precursor RNA injected into the nuclei of $X$. laevis oocytes is rapidly transported to the cytoplasm (Yang et al. 1992). The $5^{\prime} \mathrm{m}^{7} \mathrm{G}$ cap structure of pre-U1 RNA has been implicated as an important signal for U1 RNA export because reduced levels of pre-U1 RNA were detected in the cytoplasm when excess $m^{7} \mathrm{G}$ cap analog was injected or when the U1 RNA was made with a $5^{\prime}$ triphosphate end by transcription from an RNA polymerase III promoter (Hamm and Mattaj 1990; Izaurralde et al. 1992). However, it is unclear whether this reduction was solely the result of direct effects on export. Furthermore, these studies did not address the possibility that pre-Ul RNA might contain additional signals for export.

In this study we show that export of U1 RNA involves two domains present in the $5^{\prime}$ and $3^{\prime}$ regions of the RNA, each of which can act independently of the other to promote export. Also, we demonstrate that although the $5^{\prime}$ $\mathrm{m}^{7} \mathrm{G}$ cap structure of precursor U1 RNA enhances the rate of U1 snRNA export significantly, it is neither sufficient nor essential for snRNA export. The localization of U6 RNA exclusively in the nucleus is most likely the result of the lack of export signals rather than the presence of active retention signals.

\section{Results}

We investigated the stability and intracellular localization of U snRNAs in X. laevis oocytes by microinjecting either snRNA genes (plus $\left[{ }^{32} \mathrm{P}\right] \mathrm{GTP}$ ) or ${ }^{32} \mathrm{P}$-labeled precursor snRNAs. Individual oocytes were dissected at various times into nuclear and cytoplasmic fractions, and the intracellular distributions of the labeled RNAs were determined by polyacrylamide gel electrophoresis. Because the distribution of an RNA is a function of both its transport and stability, we also examined the stability of the RNAs within each cell compartment. Notably, we found that several RNAs were unstable in the nucleus although they were stable in the cytoplasm. The accuracy of nuclear injections and the quality of oocyte dissections were monitored by coinjection of U6 RNA, because this RNA is not exported from the nucleus (Hamm and Mattaj 1989) and is stable in both compartments of the oocyte (see below).
The $\mathrm{m}^{7} G 5^{\prime}$ cap structure is neither sufficient nor necessary for snRNA export

To determine whether the $\mathrm{m}^{7} \mathrm{G}$ cap structure and transcription by RNAP II are sufficient to direct the export of an snRNA, we made a chimeric gene with an RNAP II promoter from a U1 RNA gene placed upstream of the coding sequence of U6 RNA (Fig. 1A). Normally, U6 RNA is synthesized by RNAP III (for review, see Reddy and Singh 1992), lacks an $\mathrm{m}^{7} \mathrm{G}$ cap structure, and is not exported to the cytoplasm (Hamm and Mattaj 1989; Vankan et al. 1990). The U6 RNA that is made after injection of the chimeric template was localized solely in the nucleus (Fig. 1B, RNAP II), thus behaving like U6 RNA that is made from the normal U6 promoter (RNAP III). This U6 RNA contained an $\mathrm{m}^{7} \mathrm{G}$ cap because it was precipitated by antibodies specific for this cap (Fig. 1C), as was the $\mathrm{m}^{7} \mathrm{G}$-capped pre-Ul RNA /which, as expected, constituted only a minor fraction of the total Ul RNA; Dahlberg and Lund 1988).

The localization in the nucleus of U6 RNA made from a U1 promoter contrasts with the export of U1 RNA synthesized from the same promoter (i.e., the transcript

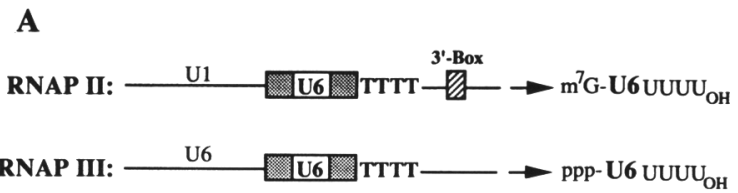

B

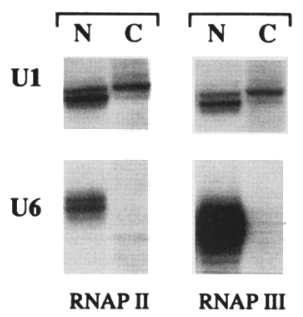

C

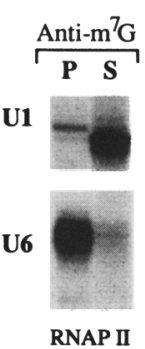

Figure 1. An $\mathrm{m}^{7} \mathrm{G}$ cap is not sufficient for export of U6 RNA from the nucleus. $(A)$ Structure of templates used to express U6 RNA from a U1 promoter (RNAP II) or a U6 promoter (RNAP III). The U6-coding sequences (stippled region), the U1 $3^{\prime}$-end signal ( $3^{\prime}$ 'box), and the $5^{\prime}$ and $3^{\prime}$ ends of the primary U6 RNA transcripts are indicated. $(B)$ Intracellular location of U6 RNAs synthesized by either RNAP II or III. Xenopus oocytes were coinjected with wild-type Ul genes $(\sim 4 \mathrm{ng}$ of DNA/oocyte) and either the chimeric (RNAP II) or wild-type (RNAP III) U6 RNA genes $\mid \sim 4$ and $1 \mathrm{ng}$ of DNA/oocyte, respectively) plus $\left[\alpha^{32} \mathrm{P}\right]$ GTP. After $5 \mathrm{hr}$ of labeling, 1 oocyte equivalent of the ${ }^{32} \mathrm{P}$-labeled RNA present in the nuclear $(\mathrm{N})$ and cytoplasmic $(\mathrm{C})$ fractions from 10 pooled oocytes was analyzed by electrophoresis in a denaturing $8 \%$ polyacrylamide gel. The autoradiographs of the U6 and U1 RNA regions of the gel are shown. $(C)$ Immunoprecipitation analysis using antibodies against the $5^{\prime} \mathrm{m}^{7} \mathrm{G}$ cap structure. Precipitation was carried out with 3 oocyte equivalents of nuclear RNAs shown in the left panel of $B$, and both pellet $(P)$ and supernatant $(S)$ were analyzed by gel electrophoresis as in $B$. 
of a coinjected U1 gene; Fig. 1B, top bands). Because $\mathrm{m}^{7} \mathrm{G}$ capped U6 RNA is stable following its injection into the cytoplasm (see Table 1 footnote, below; data not shown), it is unlikely that $\mathrm{m}^{7} \mathrm{G}$ capped U6 RNA was exported from the nucleus and degraded rapidly in the cytoplasm. We conclude that synthesis from a Ul promoter and possession of an $\mathrm{m}^{7} \mathrm{G}$ cap structure are not sufficient to specify snRNA export. In support of this conclusion, we have found that several comparably sized $\mathrm{m}^{7} \mathrm{G}$-capped RNAs, such as antisense U4 RNA and artificial RNAs generated by transcription from $\mathrm{pGEM}$ vectors and DNA fragments containing SP6 and T7 RNA polymerase promoters, were either unstable or not exported from the nucleus (data not shown).

We tested directly whether the $\mathrm{m}^{7} \mathrm{G}$ cap was necessary for U1 RNA export by monitoring the transport of differently capped precursor U1 RNAs that were injected into oocyte nuclei (Fig. 2). These precursor U1 RNAs, made in vitro using SP6 RNA polymerase, had either a nonphysiological ApppG or $\mathrm{m}^{7} \mathrm{GpppG}$ and $\gamma$-mpppG cap structures, which are normally present at the 5 ' ends of pre-U1 and U6 RNAs, respectively. To assay for export of Ul RNA in the absence of its import (Hamm and Mattaj 1990), in these and other experiments we used a variant U1 RNA, Ul Sm $^{-}$(Fig. 4A, below), which lacks the Smbinding site needed for import (Hamm et al. 1987). Control experiments indicated that the export rate and stability of $U 1_{S_{m}}-$ RNA were similar to those of wild-type U1 RNA (data not shown), and so in the text below we refer to these RNAs synonymously unless indicated otherwise.

As shown in Figure 2A (lanes 2-5), U1 RNAs with the different $5^{\prime}$ caps accumulated in the cytoplasm. These RNAs with alternative cap structures (either ApppG or $\gamma$-mpppG caps/ were exported to the cytoplasm, although at a two- to threefold slower rate than $\mathrm{m}^{7} \mathrm{G}$-capped $\mathrm{Ul}$ RNA (Figs. 2B and 3B; data not shown). Again, export of ApppG-capped U1 RNA was independent of the presence of the Sm protein-binding site in the RNA /data not shown). As expected, the coinjected control U6 RNA remained in the nucleus (lower panel). In contrast to uncapped U1 RNA, which is highly unstable in both the nucleus and cytoplasm (data not shown; cf. Hamm and Mattaj 1990), the cap-substituted U1 RNAs were quite stable in both compartments. Thus, the $\mathrm{m}^{7} \mathrm{G}$ cap enhanced the rate of U1 RNA export, but it was not essential for export of U1 RNA.

\section{The dinucleotide $\mathrm{m}^{7}$ GpppG destabilizes pre-U1 RNAs in the nucleus}

We examined possible functional interactions of the $\mathrm{m}^{7} \mathrm{G}$ cap of pre-U1 RNA with nuclear components by injecting an analog of the cap, the dinucleotide $\mathrm{m}^{7} \mathrm{GpppG}$, which would be expected to compete for association with cap-binding proteins (Izaurralde et al. 1992). To understand the effects of this compound on transport of pre-U1 RNA, it was first important to know whether it affected RNA stability. As shown in Figure 3, coinjection of the $\mathrm{m}^{7} \mathrm{G}$ cap analog significantly de-
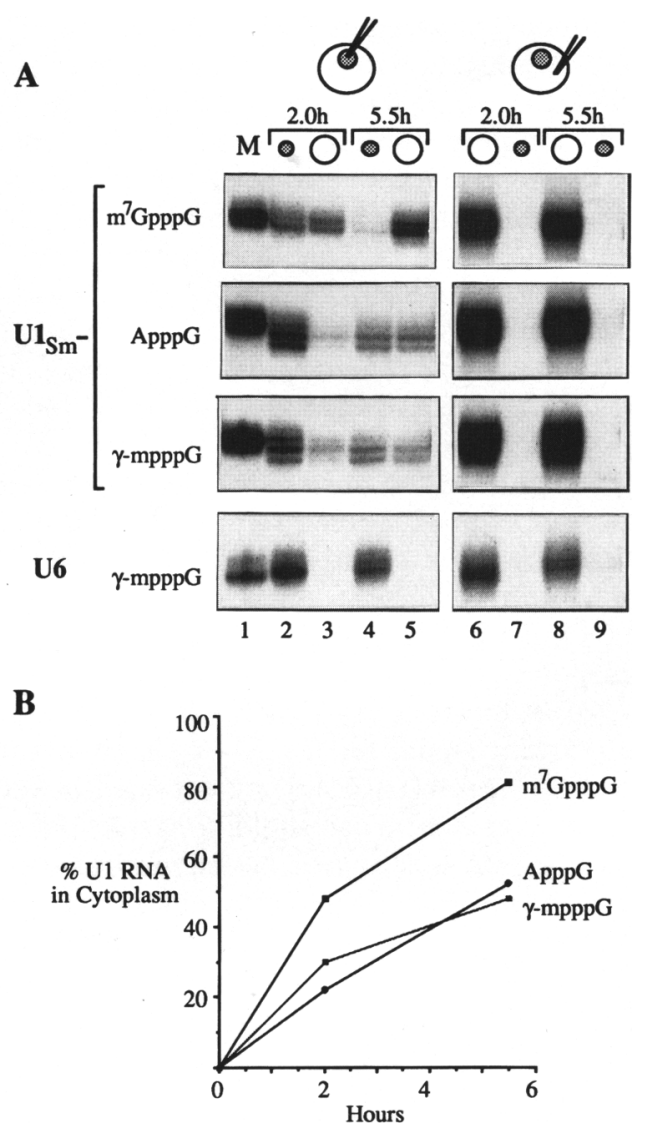

Figure 2. An $\mathrm{m}^{7} \mathrm{G}$ cap is not necessary for export of Ul RNA from the nucleus. $(A)$ Export from the nucleus of precursor U1 RNAs containing different $5^{\prime}$ cap structures. ${ }^{32} \mathrm{P}$-labeled precursor $\mathrm{Ul}_{\mathrm{Sm}^{-}}$RNAs (see text; Fig. $4 \mathrm{~A}$ ) containing $\mathrm{m}^{7} \mathrm{GpppG}$, ApppG, or $\gamma$-mpppG caps were synthesized in vitro using SP6 RNA polymerase and injected into either oocyte nuclei (lanes 2-5) or cytoplasms (lanes $6-9$ ), as indicated. To control for the accuracy of nuclear injections and quality of oocyte dissections, $\gamma$-mpppG-capped U6 ( $\Delta \mathrm{ss}$ ) RNA (bottom) was coinjected with each RNA; U6 RNA is not exported from the nucleus (see text). After 2 and $5.5 \mathrm{hr},{ }^{32} \mathrm{P}$-labeled RNAs present in the nuclear (lanes $2,4,7,9$ ) and cytoplasmic (lanes 3,5,7,9) fractions of individual oocytes were isolated and analyzed by polyacrylamide gel electrophoresis as in Fig 1B. (Lane 1) The RNAs before injection. (B) Quantitation of the results shown in $A$, lanes 2-5). The autoradiographs were scanned, and the percentage of injected pre-Ul RNA that was in the cytoplasm is plotted as a function of time after injection of the RNAs into the nucleus.

creased the stability of $\mathrm{m}^{7} \mathrm{G}$-capped U1 RNA precursors in the nucleus but not the cytoplasm /Fig. 3A, $\mathrm{Ul}_{\mathrm{Sm}^{-}}$, lanes 2-9; summarized in Fig. 3B, left panels). Surprisingly, this analog also destabilized U1 RNA, whose 5' cap was ApppG rather than $\mathrm{m}^{7} \mathrm{GpppG}$ (Fig. 3B, middle panels; see Discussion). In contrast, variants of U1 RNA (see Fig. 4A) such as $\mathrm{U} 1_{124}$ (lacking sequences at the $3^{\prime}$ end) or $U 1_{\text {Mini }}$ (lacking sequences from the middle of $U 1$ RNA/ were not destabilized appreciably by the cap ana$\log$ (Fig. 3B, right panels; data not shown). As expected $\mathrm{m}^{7} \mathrm{GpppG}$ did not affect the stability of U6 RNA or 
$\mathbf{A}$

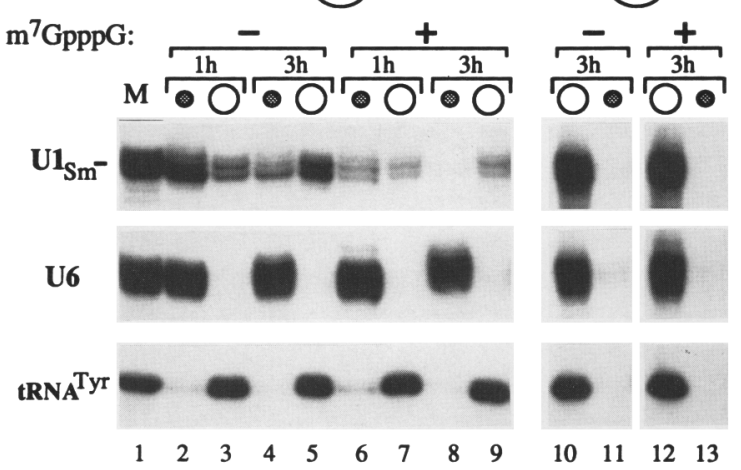

B

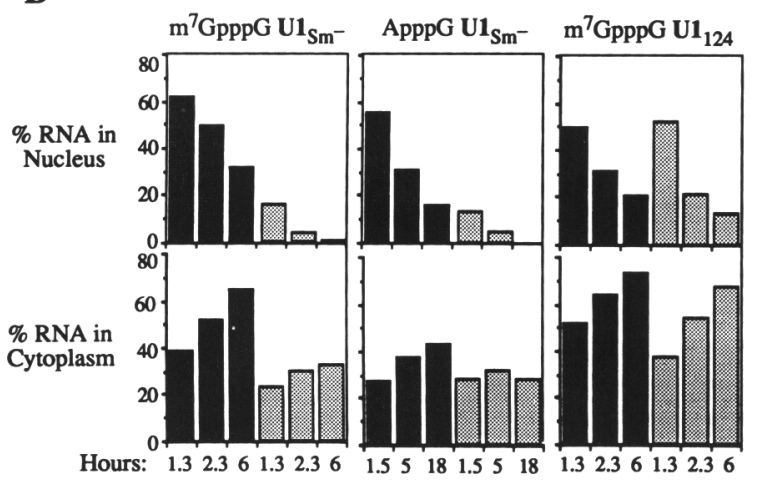

Figure 3. The $\mathrm{m}^{7} \mathrm{GpppG}$ cap analog specifically destabilizes full-length pre-U1 RNAs in the nucleus. $(A)$ Effect of the $\mathrm{m}^{7} \mathrm{GpppG}$ cap analog on the metabolism of several different types of RNAs. A mixture of $\mathrm{m}^{7} \mathrm{G}$-capped $\mathrm{Ul}_{\mathrm{Sm}^{-}}$RNA, $\gamma$-mpppG-capped U6 RNA, and $X$. laevis mature tRNA ${ }^{\text {Tyr }}$ (all labeled with ${ }^{32} \mathrm{P}$ ) was injected into oocyte nuclei (lanes 2-9) or cytoplasms (lanes 10-13) in the presence $(+)$ or absence $(-)$ of 50 $\mathrm{mM} \mathrm{m}^{7} \mathrm{GpppG}$ cap analog. After 1 and $3 \mathrm{hr}$ of incubation, the intracellular distributions of the RNAs were analyzed as in Fig. $2 \mathrm{~A}$; lane 1 shows the RNA prior to injection. $(B)$ Quantitation of the effects of the $m^{7} \mathrm{GpppG}$ cap analog on export and stabilities of $\mathrm{m}^{7} \mathrm{G}$ - or ApppG-capped $\mathrm{U}_{\mathrm{Sm}^{-}}$RNA and $\mathrm{m}^{7} \mathrm{G}$-capped $\mathrm{Ul}_{124}$ RNA. The results of experiments such as those shown in $A$ were quantitated by scanning the autoradiographs; the bars show the percentage of the injected RNAs present in the nuclear $\mid$ top $\mid$ and cytoplasmic fractions (bottom) at different times after injections in the presence (shaded bars) or absence (solid bars) of the $\mathrm{m}^{7} \mathrm{GpppG}$ cap analog.

tRNA $^{\text {Tyr }}$ nor the transport of the tRNA (Fig. 3A, lanes 2-9).

The effect of the cap analog on U1 RNA export was difficult to evaluate because of the destabilization of the RNA. However, at early times after coinjection of the cap analog and pre-U1 RNA, before the RNA in the nucleus had been degraded, a significant level of export occurred (Fig. 3A, lanes 6,7; see 1.3-hr time point in bottom left panel of Fig. 3B). Moreover, the export rate of stable $\mathrm{m}^{7} \mathrm{G}$-capped U1 RNA variants, such as $\mathrm{Ul}_{124}$ and $\mathrm{U} 1_{\text {Mini }}$, was inhibited only slightly (Fig. 3B, bottom right panel; data not shown). Thus, it is very likely that the dinucleotide $\mathrm{m}^{7} \mathrm{GpppG}$ affects the stability of full-length precursor U1 RNA in the nucleus more than it affects the export of this RNA.

\section{Sequences within U1 RNA that signal RNA export}

We asked whether sequences within U1 RNA might direct its export. As noted above (Fig. 3B), two deletion variants of U1 RNA were stable and efficiently exported from the nucleus. These two U1 RNA derivatives were $\mathrm{Ul}_{124}$, which lacked the $3^{\prime}$-terminal stem-loop structure of U1 RNA (Fig. 4A, middle panel), and $U 1_{\text {Mini, }}$ which contained the first 27 nucleotides from the $5^{\prime}$ end and the entire 3' stem-loop sequences but lacked the majority of internal U1 RNA sequences, including the Sm protein-binding site (Fig. 4A, right panel). Both of these RNAs were exported from the nucleus at rates comparable with that of the full-length $\mathrm{U} 1_{\mathrm{Sm}^{-}}$RNA (Fig. 4B). Lacking functional $\mathrm{Sm}$ protein-binding sites, the deletion variants remained in the cytoplasm, where they were stable (data not shown). The $5^{\prime} 27$ nucleotides of U1 $1_{\text {Mini }}$ RNA are not essential for export, because comparable minimal U1 RNAs that lacked these $5^{\prime}$ sequences, but contained the $3^{\prime}$-terminal stem-loop structure (Sumpter et al. 1992), were also very efficiently exported (data not shown). These results suggest that U1 RNA contains two signals present in the $5^{\prime}$ and $3^{\prime}$ regions of the RNA, each of which can act independently of the other to promote export.

As with full-length $\mathrm{U} 1_{\mathrm{sm}}$ - RNA (Fig. 2), substitution of the $\mathrm{m}^{7} \mathrm{G}$ cap with an ApppG reduced the rate of export of $\mathrm{U} 1_{\text {Mini }}$ RNA two to threefold (data not shown). However, in the case of $\mathrm{U}_{124}$ RNA, the identical cap substitution resulted in a much greater reduction in the rate of export (approximately eightfold; data not shown). This result indicates that the function of the $5^{\prime}$ export signal is more dependent on the $\mathrm{m}^{7} \mathrm{G}$ cap structure than that of the $3^{\prime}$ signal.

\section{Export sequences of U1 RNA can function to direct export of heterologous RNA}

To test whether the $5^{\prime}$ and $3^{\prime}$ U1 RNA domains were capable of directing export of another RNA, we fused these U1 RNA sequences to the U6 RNA (Fig. 5A); this RNA is otherwise not exported from the nucleus even when it contains an $\mathrm{m}^{7} \mathrm{G}$ cap (Fig. 1). When injected into nuclei, hybrid U6 RNAs containing either the $5^{\prime}$ domain (nucleotides 1-124) or the $3^{\prime}$ domain (nucleotides 130164) of U1 RNA were exported. Thus, both domains contain signals that can promote export of a heterologous RNA (Fig. 5B, lanes 2-7). However, the hybrid RNAs were not transported as efficiently as was full-length $\mathrm{U} 1$ RNA (Fig. 5B, cf. RNAs in lanes 4 and 5). Because either domain of U1 RNA by itself can direct export of U6 RNA, two separate export signals apparently exist within U1 RNA.

\section{Dual role for sequences within the 3' stem-loop of U1 RNA}

We investigated the role of the $3^{\prime}$-end structure in Ul 
Figure 4. Sequences within both the $5^{\prime}$ and $3^{\prime}$ domains of pre-U1 RNA are sufficient for export. (A) Structures of full-length $\mathrm{U} 1_{\mathrm{Sm}^{-}}$RNA (left), $\mathrm{Ul}_{124}$ RNA, containing only the $5^{\prime}$ proximal 124 nucleotides of U1 RNA (middle), and $\mathrm{Ul}_{\mathrm{Mini}}$ RNA, lacking internal Ul sequences between nucleotides 27 and 130 (right). The positions of the major stem-loop domains (I-IV) and the substitution of the $\mathrm{Sm}$ protein-binding site sequences (open box) are indicated. All three RNAs lack a functional Sm protein-binding site and are not imported from the cytoplasm to the nucleus. $(B) \mathrm{Ki}$ netics of nuclear export of $\mathrm{Ul}_{\mathrm{Sm}^{-}}$and $\mathrm{Ul}_{124}$, and $\mathrm{Ul}_{\text {Mini }}$ RNAs. Mixtures of the $\mathrm{m}^{7} \mathrm{G}$-capped RNAs (as indicated) were injected into nuclei, and the intracellular distribution of the RNAs was analyzed by electrophoresis in a $8 \%$ polyacrylamide gel after different times of incubation. The times were $1.3 \mathrm{hr}$ (lanes 2,5), $2.3 \mathrm{hr}$ (lanes 3,6), and $6 \mathrm{hr}$ (lanes 4,7) (left) and $0.5 \mathrm{hr}$ (lanes 9,13), $1 \mathrm{hr}$ (lanes $10,14), 3 \mathrm{hr}$ (lanes 11,15), and $8 \mathrm{hr}$ (lanes 12,16) (right). Lanes 1 and 8 show the RNAs before injection.
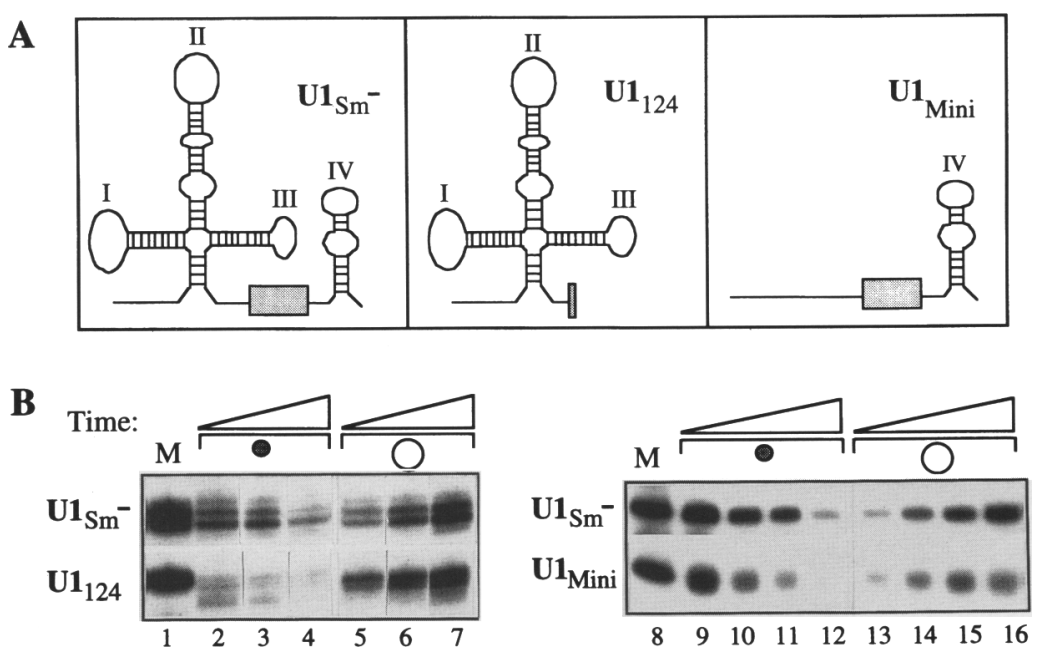

RNA export and stability by injecting several variant U1 RNAs containing either extensions or truncations at the $3^{\prime}$ ends (Fig. 6A). Unexpectedly, the $\mathrm{m}^{7} \mathrm{G}$-capped $\mathrm{Ul}+40$, $\mathrm{Ul}_{+8}$, and $\mathrm{Ul}_{153}$ RNAs were degraded rapidly when injected into the nucleus (Fig. 6B, lanes 2-5); these same RNAs were stable for at least $24 \mathrm{hr}$ when injected into the cytoplasm (lanes 6,7; data not shown). Only the wildtype precursor U1 RNA, $\mathrm{U} 1_{+2}$ (with 2 extra nucleotides at the 3 ' end), was stable and exported efficiently; a low amount of RNA in the $\mathrm{U} 1_{+8}$ preparation also was stable and exported, as evidenced by the appearance of shortened, mature forms back in the nucleus $3 \mathrm{hr}$ later (lane 4). Thus, in addition to its role in export, the correct 3 '-end structure of pre-U1 RNA contributes greatly to the stability of the RNA in the nucleus.

\section{The roles of U6 RNA termini for stability} and retention in the nucleus

The localization of newly made U6 RNA in the nucleus could result either from a lack of export signals in the RNA or from active retention. To distinguish between these two possibilities, we tested three sites within the U6 RNA for their abilities to keep the RNA in the nucleus (Fig. 7A). These were (1) the $5^{\prime}$ cap, (2) the singlestranded region (nucleotides 20-25), which is important for both 5' capping (Singh et al. 1990) and import of U6 RNA from the cytoplasm to the nucleus (Hamm and Mattaj 1989), and (3) the $3^{\prime}$-terminal uridylate tract that serves as a binding site for the karyophillic La protein (Rinke and Steitz 1985; Reddy et al. 1987; Terns et al. 1992) and is subject to post-transcriptional modification (Lund and Dahlberg 1992; Tazi et al. 1993).

An example of these studies is shown in Figure 7B, in which $\gamma$-mpppG-capped U6 RNA lacking the 3' uridylate stretch was injected into oocyte nuclei (lanes 2,3 ) or cytoplasms (lanes 4,5). Some of the $3^{\prime}$ truncated U6 RNA was elongated, apparently by nontemplated addition of a 3' uridylate tract (Lund and Dahlberg 1992), in both cell compartments (lanes 2,5) to the point where it could bind La protein, as shown by its coprecipitation by anti$\mathrm{La}$ antibodies (Fig. 8C). However, even the fraction of U6 RNA that was not elongated remained in the nucleus, making it unlikely that the nuclear localization of U6 RNA was the result of retention of the RNA via binding to the La protein.

The stabilities and subcellular localization of this and other U6 RNA variants following injection into oocyte nuclei are summarized in Table 1 . Maximal stability of U6 RNA in the nucleus was dependent on the presence of both the 5' cap structure and the 3'-terminal uridylate tract (La-binding site). Deletion of the single-stranded region did not significantly affect the nuclear stability of U6 RNA containing wild-type termini. Variable effects on U6 RNA stability were observed when both the single-stranded region and the $5^{\prime}$ or $3^{\prime}$ termini were altered. The half-lives of all variants of U6 RNA were generally two- to fourfold longer in the cytoplasm than in the nucleus (not shown); it is therefore unlikely that export of U6 RNAs went undetected as a result of cytoplasmic degradation. Moreover, the U6 RNA variants probably did not undergo a rapid export/import cycle, because U6 RNAs lacking the single-stranded region needed for efficient import into the nucleus from the cytoplasm (Hamm and Mattaj 1989) did not accumulate in the cytoplasm. These data show that U6 RNA remains in the nucleus regardless of the type of $5^{\prime}$ cap that it has or whether it contains the single-stranded region and/or the $3^{\prime}$-terminal uridylate stretch. Thus, it is likely that U6 RNA lacks signal sequences necessary for RNA export. 
$\mathbf{A}$

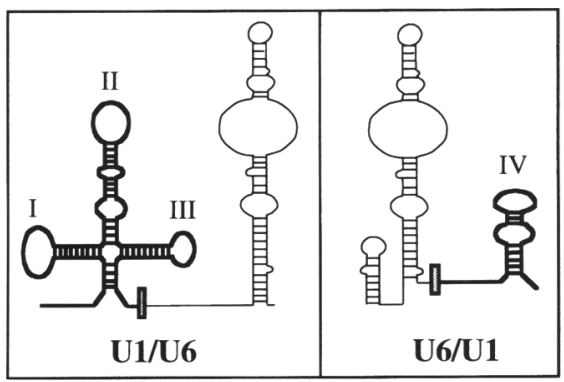

B
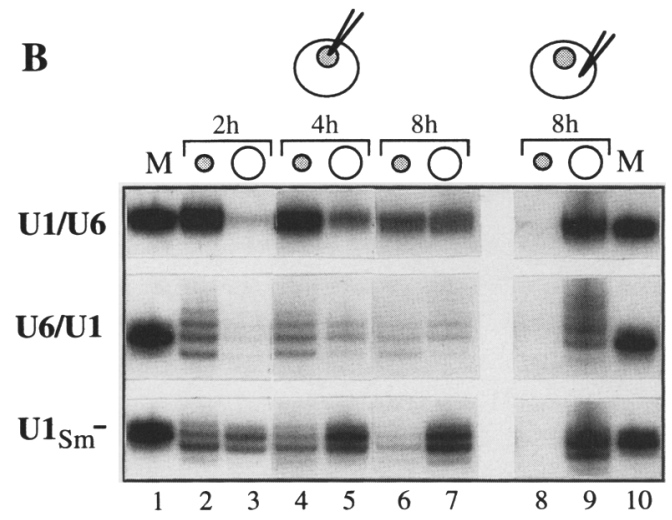

Figure 5. The 5' and $3^{\prime}$ export domains of U1 RNA can direct export of U6 RNA sequences from the nucleus. (A) Structures of the hybrid snRNAs with Ul sequences in boldface type. The U1/U6 RNA contains the $5^{\prime}$ domain of U1 RNA /nucleotides

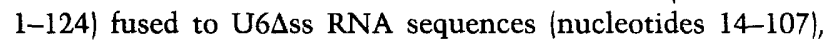
and U6/U1 hybrid RNA contains the $3^{\prime}$-terminal stem-loop of U1 RNA fused to the $3^{\prime}$ end of U6 1 ss RNA; U6/U1 RNA does not contain the $\mathrm{Sm}$ protein-binding site of U1 RNA and lacks nucleotides 20-25 of U6 RNA that are important for nuclear import of U6 RNA (Hamm and Mattaj 1989). (B) Kinetics of nuclear export of $\mathrm{U}_{\mathrm{Sm}^{-}}$and $\mathrm{U1} / \mathrm{U} 6$ and $\mathrm{U} 6 / \mathrm{U} 1$ hybrid snRNAs. All three $\mathrm{m}^{7} \mathrm{G}$ capped RNAs were coinjected into oocyte nuclei (lanes 2-7) or cytoplasms (lanes 8,9), and export was assayed as in Fig. 2A; lanes 1 and 10 show the RNAs before injection. U1/U6 RNA was stable in both the nuclear and cytoplasmic compartments, whereas U6/U1 RNA was somewhat less stable in the nucleus than in the cytoplasm. However, the apparent reduction in total levels of U6/U1 RNA after nuclear injection resulted primarily from generation of multiple bands of $3^{\prime}$ elongated forms (of unknown identity), similar to those seen after injection into the cytoplasm (see lanes 9,10).

\section{Discussion}

In analyzing cis-acting signals that participate in the export and stabilization of RNAs, we studied the precursors of two snRNAs, U1 and U6. Specific structures at the $5^{\prime}$ and $3^{\prime}$ ends of both RNAs are needed for their stability within the nucleus. Our results are consistent with the idea that export is not the default pathway for snRNAs. Two sequence domains within UI RNA were identified that, in conjunction with the $5^{\prime} \mathrm{m}^{7} \mathrm{G}$ cap structure, direct efficient U1 RNA export. U6 RNA appears to lack such export signals, which may explain why this RNA remains in the nucleus.

\section{Export signals in pre-U1 RNA}

The two sequence elements of pre-U1 RNA that promote export from the nucleus to the cytoplasm are located in the $3^{\prime}$ stem-loop and within the $5^{\prime}$-terminal, 124 nucleotides of this RNA, respectively. Variants of pre-U1 RNA lacking one or the other sequence element are exported (Fig. 4), indicating that neither element is essential and that the individual sequence elements can function independently of each other. When fused to U6 RNA, either element is able to direct export of this RNA (Fig. 5). It is likely that both sequence elements contribute to the efficient export of intact pre-U1 RNAs. The precise sequences responsible for export activity remain unknown, and the actual elements may be comprised of both sequence and structural information. Moreover, sequences that direct export of pre-U1 RNA overlap, at
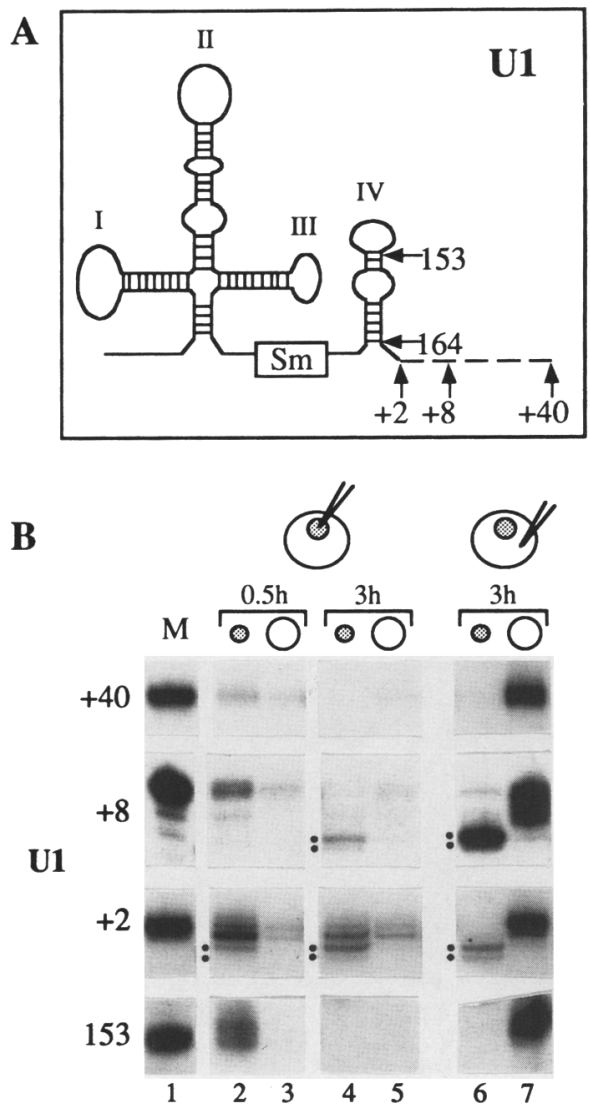

Figure 6. A correct $3^{\prime}$-terminal stem-loop structure of Ul RNA is important for both nuclear stability and import from the cytoplasm. $(A)$ Stucture of wild-type pre-U1 RNA $(\mathrm{U} 1+2)$ and variant $U 1$ RNAs that have truncated $\left(\mathrm{Ul}_{153}\right)$ or extended $\left(\mathrm{Ul}{ }_{+8}, \mathrm{U} 1_{+40}\right)^{\prime}{ }^{\prime}$ ends; all RNAs contained the Sm proteinbinding site and therefore are subject to bidirectional nuclear transport. $(B)$ Nucleocytoplasmic transport of 3 -truncated or -elongated forms of U1 RNA that were injected into oocyte nuclei (lanes 2-5) or cytoplasms (lanes 6-7). The RNAs of individual oocytes were analyzed as in Fig. $2 A_{\text {; }}$ black dots indicate mature, $\mathrm{m}_{3} \mathrm{G}$-capped $\mathrm{Ul}_{+1,0}$ RNA forms that have been imported into the nucleus. 
A

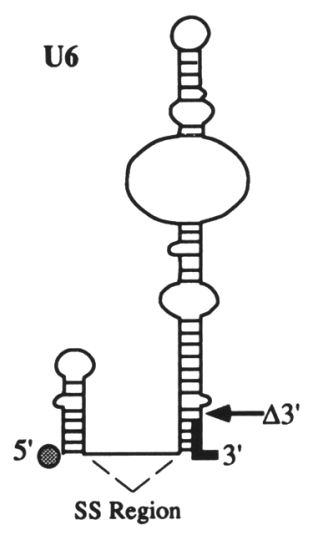

$\mathbf{B}$

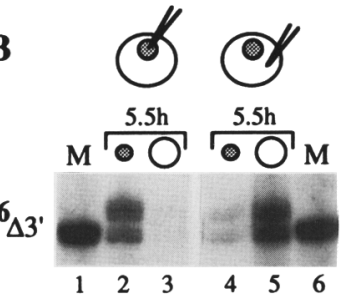

C

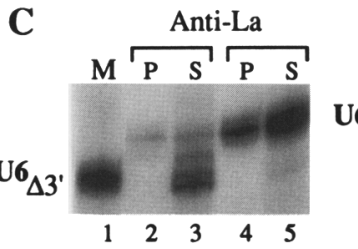

Figure 7. Deletion of the La protein-binding site does not alter the nuclear localization of U6 RNA. (A) Structure of U6 RNA showing the positions of the $5^{\prime}$ cap (shaded circle), the singlestranded (SS) region (nucleotides 20-25), and the $3^{\prime}$-terminal uridylate tract (solid region) that is the La-binding site. The arrow indicates the $3^{\prime}$ end of a truncated $U 6_{\Delta 3^{\prime}}$ RNA. $(B)$ Intracellular distribution of $\gamma$-mpppG-capped $U 6_{\Delta 3}$. RNA following injection into oocyte nuclei (lanes 2-3) or cytoplasms (lanes 4-5). Transport was assayed as in Fig. 2A. Lanes 1 and 6 show the RNA before injection. $(C)$ Immunoprecipitation of $\mathrm{U} 6$ snRNPs by anti-La antibodies. Nuclear extracts were prepared $0.5 \mathrm{hr}$ after nuclear injection of $\mathrm{U6} 6_{\Delta 3}$. RNA (lanes 2-3) or wildtype U6 RNA (lanes 4-5). U6 RNAs were purified from both the precipitate $(\mathrm{P})$ and supernatant $(\mathrm{S})$ fractions and analyzed by polyacrylamide gel electrophoresis.

least partially, with sequences required to stabilize the RNA within the nucleus (Fig. 6).

An $\mathrm{m}^{7} \mathrm{G}$ cap at the $5^{\prime}$ end of an RNA cannot be a sufficient signal to direct export, as several small RNAs, including U6 RNA, remain in the nucleus even when they contain this cap (Fig. 1). Nor is an $\mathrm{m}^{7} \mathrm{G}$ cap necessary for generating such a signal, as shown by the transport of pre-U1 RNAs that have ApppG or $\gamma$-mpppG caps

(Fig. 2). However, an $\mathrm{m}^{7} \mathrm{G}$ cap contributes to the efficiency of export because substitution of the $\mathrm{m}^{7} \mathrm{GpppG}$ cap with ApppG or $\gamma$-mpppG reduces the rate of export of full-length pre-Ul RNA two- to threefold. The influence of the $\mathrm{m}^{7} \mathrm{G}$ cap on export is more pronounced with $\mathrm{U} 1$ RNAs that lack the $3^{\prime}$ stem-loop structure, indicating that the export signals within pre-U1 RNA may act cooperatively. Without some type of cap, all U1-related RNAs are unstable.

Our results showing that an $\mathrm{m}^{7} \mathrm{G}$ cap enhances the efficiency of export of pre-Ul RNA agree with the conclusions drawn from the results of others (Hamm and Mattaj 1990; Izaurralde et al. 1992). An essential role for the 5' cap in export was suggested because a variant of pre-U1 RNA remained in the nucleus when the RNA was synthesized without a $5^{\prime}$ cap, using RNAP III (Hamm and Mattaj 1990). However, we have observed recently that such a pre-U1 RNA, in contrast to the $\mathrm{m}^{7} \mathrm{G}$ capped precursor made by RNA polymerase II, was bound to the nuclear protein La (data not shown), which normally associates with the $3^{\prime}$ ends of newly made RNA polymerase III transcripts (Rinke and Steitz 1982; Mathews and Francoeur 1984; Stefano 1984; Terns et al. 1992). Thus, it is possible that retention of this uncapped pre-U1 RNA in the nucleus was the result of masking, by the bound La protein, of the export signal at the 3 '-end structure rather than the result of the absence of a $5^{\prime}$ $\mathrm{m}^{7} \mathrm{G}$ cap.

\section{Retention of U6 RNA in the nucleus}

We cannot exclude the possibility that U6 RNA is actively retained in the nucleus through binding to an unidentified nuclear component via RNA sequences that were not tested in this study. However, our experiments indicate that the retention of U6 RNA in the nucleus results from the absence of export signals rather than from the presence of a retention element. For example, the sequences of U6 RNA are exported when they are linked to either of the export signals of pre-U1 RNA (Fig.

Figure 8. Model of precursor U1 snRNA export from the nucleus to the cytoplasm. Newly synthesized pre-Ul snRNA is rapidly assembled into a pre-export Ul snRNP particle consisting of components that protect the RNA against degradation in the nucleus. The $5^{\prime} \mathrm{m}^{7} \mathrm{G}$ cap structure, $3^{\prime}$ stemloop structure, and sequences within the $5^{\prime}$ domain of U1 RNA, all of which are important for export, may act as protein-binding sites needed to form pre-export snRNPs. Movement of the pre-export snRNP in the nucleus and through the NPC may involve recognition and specific interaction of the particle with nuclear receptor molecules

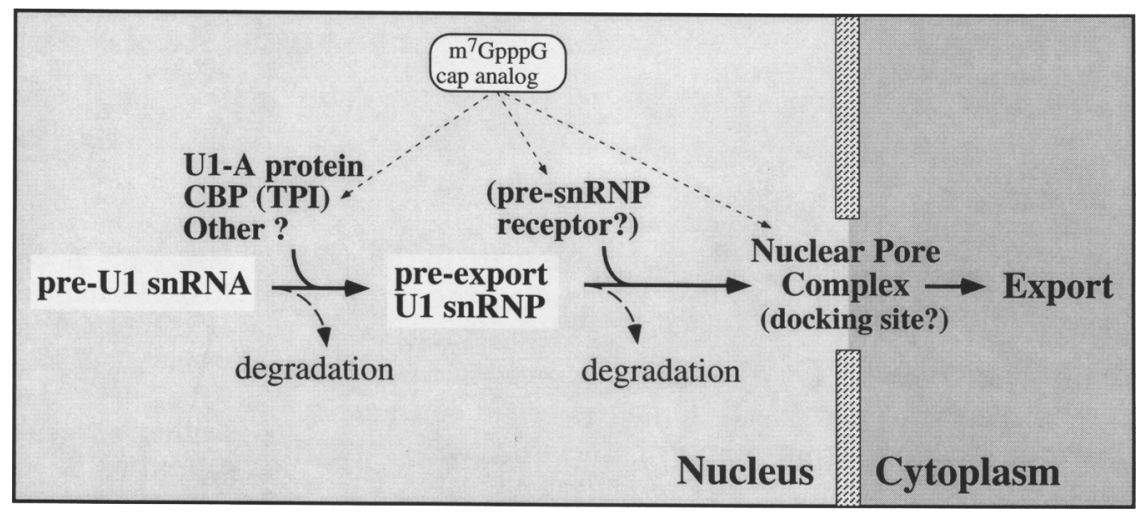
and components of the NPC. Pre-Ul snRNA that does not assemble into pre-export snRNPs or is not recognized by components of the export machinery may be degraded within the nucleus. Accordingly, competitor $\mathrm{m}^{7} \mathrm{GpppG}$ cap analog may affect both the stability and export of pre-Ul RNA by saturating cap-binding proteins normally involved in formation of pre-export snRNPs or transport of the pre-snRNPs. 
Table 1. Nuclear localization and stability of U6 RNA

\begin{tabular}{|c|c|c|c|c|}
\hline \multicolumn{3}{|c|}{ U6 RNA structure } & \multicolumn{2}{|c|}{$\begin{array}{l}\text { Behavior following } \\
\text { nuclear injection }\end{array}$} \\
\hline 5 ' end & $\begin{array}{l}\text { 3-uridylate } \\
\text { stretch }\end{array}$ & $\begin{array}{l}\text { Single- } \\
\text { stranded } \\
\text { region }\end{array}$ & $\begin{array}{l}\text { Half-life } \\
\text { in nucleus } \\
\text { (hr) }\end{array}$ & $\begin{array}{l}\text { Location } \\
\text { in oocyte }\end{array}$ \\
\hline \multirow[t]{3}{*}{ pppG } & + & + & $3-4$ & $\mathrm{~N}$ \\
\hline & + & - & $6-8$ & $\mathrm{~N}$ \\
\hline & - & + & $<0.5$ & (unstable) \\
\hline \multirow[t]{4}{*}{$\gamma$-mpppG } & + & + & $>24$ & $\mathrm{~N}$ \\
\hline & + & - & $>24$ & $\mathbf{N}$ \\
\hline & - & + & $8-12$ & $\mathbf{N}$ \\
\hline & - & - & $3-4$ & $\mathrm{~N}$ \\
\hline \multirow[t]{2}{*}{$\mathrm{m}^{7} \mathrm{GpppG}$} & + & + & $8-12$ & $\mathrm{~N}$ \\
\hline & + & - & $3-4$ & $\mathbf{N}$ \\
\hline ApppG & - & + & $8-12$ & $\mathbf{N}$ \\
\hline
\end{tabular}

Nuclear retention of U6 RNAs. U6 RNA variants with and without nucleotides 20-25 [the single-stranded region (nucleotides 20-25) required for nuclear import of U6 RNA (Hamm and Mattaj 1989)] and/or the 3'-terminal uridylate stretch (the binding site for the nuclear protein La; see Fig. 7A) were synthesized in vitro without (pppG) or with different $5^{\prime}$ caps $(\gamma$ mpppG, $\mathrm{m}^{7} \mathrm{GpppG}$, and ApppG). The ${ }^{32} \mathrm{P}$-labeled RNAs were injected into oocyte nuclei or cytoplasms, and their intracellular distribution was determined as a function of time, as in Fig. 2A. The nuclear half-lives were estimated from the autoradiographs. All U6 RNA variants tested were two- to fourfold more stable in the cytoplasm than in the nucleus (data not shown).

5). Furthermore, extensive mutations both at the ends and within the body of U6 RNA, which might destroy potential retention signal, do not result in its export / Table 1; Vankan et al. 1990). Thus, it is unlikely that the introduction of $U 1$ export elements into either end of U6 RNA disrupted a presumptive retention signal. Furthermore, most of the endogenous U6 RNA in the oocyte nucleus is not complexed with the La protein or U4 snRNPs (Terns et al. 1992). Taken together, these results indicate that U6 RNA is probably not retained within the nucleus through binding of nuclear proteins that specifically recognize U6 RNA sequences.

\section{Nuclear metabolism and export of pre-U1 snRNA}

It is likely that the export signals in pre-U1 RNA function through interactions with nuclear proteins. We have shown recently that pre-U1 RNA is in an RNP complex larger than mature U1 snRNPs, as assayed by glycerol gradient centrifugation of oocyte nuclear extracts (Terns et al. 1993). Two nuclear factors that interact with preU1 RNA are TPI, a nucleoprotein that recognizes both the $5^{\prime}$ cap and the $3^{\prime}$ end (Yang et al. 1992), and U1 snRNP protein $A$, which binds to an internal sequence of stem-loop II (Terns et al. 1993). In addition, other proteins such as the $80-\mathrm{kD}$ cap-binding protein (CBP) (Ohno et al. 1990; Izaurralde et al. 1992) very likely bind to the $\mathrm{m}^{7} \mathrm{G}$ cap of pre-U1 RNA, either independently or as part of the TPI complex. Functional interaction of TPI with the $3^{\prime}$ end of pre-U1 RNA is dependent on the presence of a $5^{\prime} \mathrm{m}^{7} \mathrm{G}$ cap and can be inhibited by excess $\mathrm{m}^{7} \mathrm{GpppG}$ dinucleotide (Yang et al. 1992). In addition, a role for the U1-A protein in stabilization is indicated by our recent finding that pre-U1 RNAs that lack both the binding site for this protein and the $\mathrm{m}^{7} \mathrm{G}$ cap are highly unstable in the nucleus (Terns et al. 1993).

We propose (Fig. 8) that pre-U1 RNA is in a specific complex, which we call a pre-export snRNP, and that such a complex both stabilizes the RNA against attack by nuclear RNases and directs the RNA to nuclear pore complexes for export to the cytoplasm. It is possible that additional proteins, acting as receptor molecules, bind transiently to bring the pre-export snRNP complex to the nuclear pore. Furthermore, there may be components at the pores that interact specifically with the pre-export snRNP-receptor complex to facilitate efficient export of the pre-snRNA.

The role of the $\mathrm{m}^{7} \mathrm{G}$ cap structure in pre-Ul RNA export has been probed by testing the effects of a dinucleotide cap analog on cytoplasmic accumulation of the RNA. In our experiments, injection of $m^{7} G p p p G$ into oocyte nuclei destabilized both $\mathrm{m}^{7} \mathrm{G}$ - and ApppGcapped, full-length pre-U1 RNA (Fig. 3; data not shown). This destabilization indicates that the RNA is normally stabilized by a cap-binding protein. Moreover, the fact that both $\mathrm{m}^{7} \mathrm{GpppG}$ - and ApppG-capped RNAs are similarly affected shows that the factor responsible (perhaps TPI or CBP) does not discriminate well between the two types of $5^{\prime}$ cap structures. Because of the destabilizing effect of the $\mathrm{m}^{7} \mathrm{GpppG}$ analog, we were unable to monitor its long-term effects on the export of injected pre-U1 RNA. However, a significant level of export occurred at early times, before the pre-Ul RNA was degraded (Fig. 3). Thus, the effects of the analog appear to be more on the stability than on the transport of pre-Ul snRNAs.

In contrast to full-length pre-U1 RNA, certain deletion variants of pre-U1 RNA were not destabilized in the presence of the cap analog (Fig. 3B). This indicates either that the variants do not require a cap-binding protein for stability (i.e., are inherently stable in the nucleus) or that their binding to this factor is relatively resistant to the dinucleotide competitor. The export of these stable variants was largely unaffected by injection of the cap analog (Fig. 3B). However, both the deletion variants and fulllength pre-U1 RNA were exported more efficiently when they contained an $m^{7} G$ cap rather than an ApppG cap. Taken together, these results suggest that a cap-binding protein (or the $\mathrm{m}^{7} \mathrm{G}$ cap structure itself) participates in the export of pre-Ul RNA and that the $\mathrm{m}^{7} \mathrm{GpppG}$ cap analog is not an effective competitor of the export of injected RNAs.

Our results contrast with previously published results of others who reported that this analog directly inhibited export of pre-U1 RNA synthesized in the nucleus (Hamm and Mattaj 1990; Izaurralde et al. 1992). The reason for this discrepancy is unclear, but the $\mathrm{m}^{7} \mathrm{GpppG}$ cap analog may act at several levels to affect both the stability and export of U1 RNA under different experimental conditions. 
The precise roles of the sequence-encoded export signals and the $5^{\prime} \mathrm{m}^{7} \mathrm{G}$ cap in stabilization and export of pre-U1 RNA remain to be defined. Clearly, these elements and structures interact with specific proteins that stabilize the RNA and promote its export either directly or through their association with components of the nuclear pore complex (Fig. 8). Identification and functional analysis of these proteins will help to clarify the mechanism of pre-snRNA nucleocytoplasmic transport. It remains to be determined whether mRNAs and snRNAs utilize common pathways for their transport from the nucleus.

\section{Materials and methods}

\section{DNA constructs}

The wild-type $X$. laevis Ul gene used in this study was U1bl (Krol et al. 1985). The mutant Ul gene (Ul $\Delta D$ ) containing a substitution of nucleotides 124-128 of the Sm protein-binding site (Hamm et al. 1987) was provided by I. Mattaj, EMBL, Heidleberg; a unique $X$ hoI site within the substituted sequence was used in generating several of the constructs described below. The wild-type Xenopus tropicales U6 gene (Krol et al. 1987) was obtained from A. Krol, and a mutant U6 gene ( $\Delta$ ss, lacking U6 nucleotides 20-25; Hamm and Mattaj 1989/ was provided by I. Mattaj.

Plasmid constructions involved standard (Innis et al. 1990) and recombinant (Higuchi 1990) polymerase chain reaction (PCR) techniques and general DNA cloning procedures (Maniatis et al. 1989). Oligonucleotides used in PCR reactions were synthesized by Promega (Madison,WI) or University of Wisconsin Biotechnology Center. pGEM3ZF + (Promega) was used as the vector for all constructs except pU1/U6, for which pUC19 was used. All DNA constructs were confirmed by DNA sequencing using the dideoxynucleotide chain-termination method with modified T7 DNA polymerase (Sequenase, U.S. Biochemical).

\section{Plasmids}

$\mathrm{pU}_{\mathrm{Sm}^{-}}$contains the $5^{\prime}$-flanking sequences (promoter) of the Ulbl gene and the coding and $3^{\prime}$-flanking sequences of the $\mathrm{U} 1 \Delta \mathrm{D}$ gene. $\mathrm{pU} 1_{\mathrm{Mini}}$ was derived from $\mathrm{pU} 1_{\mathrm{Sm}^{-}}$by deletion of coding sequences from nucleotides ${ }^{+} 27$ to ${ }^{+} 124$ (between $B c$ lI and XhoI cleavage sites) and replacement of these sequences with a BgIII linker (CAGATCTG). pU1(U6) contains the 5'flanking sequences (promoter) of the Ulbl gene, the coding region of the U6 gene, and the $3^{\prime}$-end box of the Ulbl gene. The construct was designed such that transcription starts at $G_{+1}$ of U6 and ends in a run of thymidylates generating U6 RNA containing an $\mathrm{m}^{7} \mathrm{G}$ cap and four to seven $3^{\prime}$-terminal uridylate residues. pUl(U1/U6) contains the $5^{\prime}$-flanking sequences (promoter) of the Ulbl gene and the coding sequences of $U 1 \Delta D$ (nucleotides 1-124), fused to U6Ass sequences (nucleotides 14107). The $3^{\prime}$-flanking sequences are from the Ulbl gene as in pU1(U6). pU6(U6/U1) contains the 5'-flanking sequences (promoter) of the U6 gene and the coding sequences of U6 $6 \mathrm{ss}$ (nucleotides $1-98$ ) fused to $U 1 \Delta \mathrm{D}$ sequences (begining at nucleotide 124 of the coding region and including the 3 '-flanking region). The deletion of the $3^{\prime}$-terminal thymidylate residues of the U6 RNA-coding region (within nucleotides 99-107) ensured that transcription termination occurred only at the thymidylate stretch present immediately downstream of the Ul $\Delta$ D-coding sequences (cf. Hamm and Mattaj 1990).

\section{In vitro $R N A$ synthesis}

Templates used for in vitro synthesis of $U$ snRNAs were either linearized plasmid DNAs (containing SP6 promoter sequences) or DNA fragments generated by PCR amplification of the RNAcoding regions of the plasmids described above, using appropriate $5^{\prime}$ and $3^{\prime}$ primer pairs. The $5^{\prime}$ primer used in the PCR reactions contained SP6 (all RNAs with 5' U1 RNA sequences) or T7 (all RNAs with 5' U6 sequences) phage RNA polymerase promoter sequences. The transcripts generated from these templates have the same sequence as the Xenopus pre-U1 and preU6 RNAs except for two additional residues at their 5 ' ends: GA for U1 RNA and GG for U6 RNA. The presence of the extra nucleotides at the $5^{\prime}$ end does not appear to affect the metabolism or transport of the RNAs (Terns et al. 1992; data not shown). The $3^{\prime}$-end primers were designed to give RNAs with $3^{\prime}$ ends identical to those observed in RNAs made in vivo (Neuman de Vegvar and Dahlberg 1990; Terns et al. 1992).

3 '-Altered Ul RNAs were generated by cleaving wild-type SP6-U1 templates at appropriate restriction sites, $\mathrm{U}_{153}$ (HhaI) and $\mathrm{U} 1_{+40}(E c o R I)$, or by oligonucleotide-directed RNase $\mathrm{H}$ cleavage of $\mathrm{Ul}_{+40}$ RNA to generate $\mathrm{Ul}_{+8}$ RNAs (Yang et al. 1992). $\mathrm{Ul}_{124}$ was generated by cleaving the SP6-U1 $\mathrm{Sm}^{-}$DNA template with XhoI. 3 '-truncated U6 $\Delta$ ss RNA was generated by incorporating an $N c o I$ cleavage site into a T7-U6 DNA fragment using a primer that is complementary to the $3^{\prime}$ end of U6 gene but contains two additional $\mathrm{G}$ residues between positions 101 and 102.

In vitro transcription of T7 or SP6 DNA templates was performed essentially as described previously (Terns et al. 1992), except that 5' capping of the RNAs was accomplished by lowering the GTP concentration from 500 to $50 \mu \mathrm{M}$ and including 0.5 or $1 \mathrm{~mm}$ of $\mathrm{m}^{7} \mathrm{GpppG}$ (NEB) or ApppG (Pharmacia) or $4 \mathrm{~mm}$ of $\gamma$-mpppG (kindly provided by R. Reddy, Baylor College of Medicine, Houston, TX). [ $\alpha{ }^{32}$ P]GTP (NEN Dupont) was used as source of label. To obtain RNAs with defined 3' ends (confirmed by two-dimensional RNase T1 fingerprinting analysis|, all transcripts were purified by electrophoresis in high-resolution $8 \%$ denaturing polyacrylamide gels.

\section{Oocyte microinjection analysis of RNA transport}

Stage V and VI oocytes, obtained from adult female $X$. laevis (Krol et al. 1985), were injected into the nuclei or cytoplasms with $12 \mathrm{nl}$ of solution containing up to 1 fmole of each ${ }^{32} \mathrm{P}$ labeled snRNA. The results were unaffected by a 10 -fold increase or decrease in the amount of RNA injected /data not shown). In experiments where the RNAs were coinjected with the dinucleotide cap analog, the solution contained $50 \mathrm{~mm}$ $\mathrm{m}^{7} \mathrm{GpppG}$ (New England Biolabs). For nuclear injections (which may result in partial nuclear "hits" and cytoplasmic "mishits"), at least four individual oocytes were analyzed per time point; for cytoplasmic injections (which easily avoid nuclear hits), pools of three oocytes were used. In either case, the nuclei and cytoplasms were isolated from individual oocytes by manual dissection under mineral oil (Lund and Dahlberg 1989; Lund and Paine 1990), and after proteinase K digestion, RNAs within each compartment were purified by phenol extraction and ethanol precipitation (Terns et al. 1992). The 0.5 to 1 oocyte equivalents of RNA from selected oocytes were then analyzed by electrophoresis for $3-5 \mathrm{hr}$ at $\sim 40 \mathrm{~V} / \mathrm{cm}$ in $8 \%$ (29:1) polyacrylamide gels (40 cm long and $0.4 \mathrm{~mm}$ thick) containing $7 \mathrm{M}$ urea and $0.5 \times$ TBE buffer $(45 \mathrm{~mm}$ Tris-borate at $\mathrm{pH} 8.3,1.15 \mathrm{mM}$ EDTA). Autoradiography was for $12-48 \mathrm{hr}$ with, or $1-10$ days without, an intensifying screen. Quantitation of the autoradiographs was done using AppleScan and Scan Analysis (Biosoft) software programs. 
To monitor the accuracy of the nuclear injections, U6 RNA was coinjected with the test RNAs as this RNA remains within the nucleus and is stable in both the nucleus and cytoplasm. When variant U6 RNAs were tested, $\gamma$-mpppG-capped U1/U6 hybrid RNA (which is exported very slowly from the nucleus; data not shown) was used instead. In all cases, the transport properties of injected RNAs were comparable with those of RNAs made in vivo from injected plasmid DNAs.

\section{Immunoprecipitation}

Extract preparation from isolated nuclei and cytoplasms and immunoprecipitations were performed as described previously (Terns et al. 1992). The antibodies used in these experiments include a monoclonal (Y12) anti-Sm antibody (Lerner et al. 1981) (from J. Steitz, Yale University, New Haven, CT), rabbit polyclonal antibodies against the $\mathrm{m}_{3} \mathrm{G}$ cap (Bringmann et al. 1983) (from R. Lührmann) or $m^{7} G$ cap antibodies (Munns et al. 1982) (from T. Munns), and anti-La patient sera (A-114 and A-306; described in Terns et al. 1992) (from D. Kenan and J. Keene, Duke University, Durham, NC).

\section{Acknowledgments}

We thank A. Krol and I. Mattaj for supplying U1 and U6 genes, R. Reddy for furnishing the $\gamma$-mpppG cap analog, and J. Steitz, R. Lührmann, T. Munns, D. Kenan, and J. Keene for providing antibodies used in this study. This work was supported by a grant from the National Institutes of Health (NIH) (GM30220) to J.E.D. and an NIH postdoctoral fellowship (GM14704) to M.P.T.

The publication costs of this article were defrayed in part by payment of page charges. This article must therefore be hereby marked "advertisement" in accordance with 18 USC section 1734 solely to indicate this fact.

\section{References}

Bataille, N., T. Helser, and H.M. Fried. 1990. Cytoplasmic transport of ribosomal subunits microinjected into the Xenopus laevis oocyte nucleus: A generalized, facilitated process. $J$. Cell. Biol. 111: 1571-1582.

Bringmann, P., J. Rinke, B. Appel, R. Reuter, and R. Lührmann. 1983. Purification of snRNPs U1, U2, U4, U5, and U6 with 2,2,7-trimethylguanosine-specific antibody and definition of their constiuent proteins reacting with anti-Sm and anti(U1) RNP antisera. EMBO I. 2: 1129-1135.

Dahlberg, J.E. and E. Lund. 1988. The genes and transcription of the major small nuclear RNAs. In Structure and function of the major and minor small nuclear ribonucleoprotein particles (ed. M.L. Birnsteil), pp. 38-70. Springer-Verlag, Heidelberg, Germany.

Dargemont, C. and L.C. Kühn. 1992. Export of mRNA from microinjected nuclei of Xenopus laevis oocytes. J. Cell. Biol. 118: $1-9$.

Dworetzky, S.I. and C.M. Feldherr. 1988. Translocation of RNA-coated gold particles through the nuclear pores of oocytes. J. Cell. Biol. 106: 575-584.

Eckner, R., W. Ellmeir, and M. Birnstiel. 1991. Mature mRNA 3' end formation stimulates RNA export from the nucleus. EMBO /. 10: 3513-3522.

Featherstone, C., M. Darby, and L. Gerace. 1988. A monoclonal antibody against the nuclear pore complex inhibits nucleocytoplasmic transport of protein and RNA in vivo. I. Cell. Biol. 107: 1289-1297.

Feeney, R.J. and G.W. Zieve. 1990. Nuclear exchange of the U1 and U2 snRNP-specific proteins. J. Cell. Biol. 110: 871-881. Fischer, U. and R. Lührmann. 1990. An essential signalling role for the $m_{3} G$ cap in the transport of $U 1$ snRNP to the nucleus. Science 249: 786-790.

Fischer, U., E. Darzynkiewicz, S.M. Tahara, N.A. Dathan, and R. Lührmann. 1991. Diversity in the signals required for the nuclear accumulation of $U$ snRNPs and variety in the pathways of nuclear transport. J. Cell. Biol. 113: 705-714.

Fischer, U., V. Sumpter, M. Sekine, T. Satoh, and R. Lührmann. 1993. Nucleocytoplasmic transport of U snRNPs: Definition of a nuclear localization signal in the Sm core domain that binds a transport receptor independently of the $m_{3} G$ cap. EMBO J. 12: 573-583.

Forbes, D.J. 1992. Structure and function of the nuclear pore complex. Annu. Rev. Cell Biol. 8: 495-527.

Green, M.R. 1991. Biochemical mechanisms of constitutive and regulated pre-mRNA splicing. Annu. Rev. Cell Biol. 7: 559599.

Guddat, U., A. H. Bakken, and T. Pieler. 1990. Protein-mediated nuclear export of RNA: 5S rRNA containing small RNPs in xenopus oocytes. Cell 60: 619-628.

Hamm, J. and I.W. Mattaj. 1989. An abundant U6 snRNP found in germ cells and embryos of Xenopus laevis. EMBO J. 8: $4179-4187$.

- 1990. Monomethylated cap structures facilitate RNA export from the nucleus. Cell 63: 109-118.

Hamm, J., E. Darzynkiewicz, S.M. Tahara, and I.W. Mattaj. 1990. The trimethylguanosine cap structure of U1 snRNA is a component of a bipartite nuclear targeting signal. Cell 62: $569-577$.

Hamm, J., M. Kazmaier, and I. Mattaj. 1987. In vitro assembly of U1 snRNPs. EMBO 1. 6: 3479-3485.

Higuchi, R. 1990. Recombinant PCR. PCR protocols: A guide to methods and applications, chapter 22, pp. 177-183. Academic Press, Inc./Harcourt Brace Jovanovich, Publishers, San Diego, CA.

Innis, M.A., D.H. Gelfand, J.J. Sninsky, and T.J. White. 1990. PCR protocols: $A$ guide to methods and applications, pp. 482. Academic Press, Inc./Harcourt Brace Jovanovich, Publishers, San Diego, CA.

Izaurralde, E. and I.W. Mattaj. 1992. Transport of RNA between nucleus and cytoplasm. Sem. Cell Biol. 3: 279-288.

Izaurralde, E., J. Stepinski, E. Darzynkiewicz, and I.W. Mattaj. 1992. A cap binding protein that may mediate nuclear export of RNA polymerase II-transcribed RNAs. I. Cell. Biol. 118: 1287-1295.

Jantsch, M.F. and J.G. Gall. 1992. Assembly and localization of the U1-specific snRNP C protein in the amphibian oocyte. $J$. Cell. Biol. 119: 1037-1046.

Kambach, C. and I.W. Mattaj. 1992. Intracellular distribution of the UIA protein depends on active transport and nuclear binding to U1 snRNA. I. Cell. Biol. 118: 11-21.

Krol, A., E. Lund, and J.E. Dahlberg. 1985. The two embryonic U1 RNA genes of Xenopus laevis have both common and gene-specific transcription signals. EMBO J. 4: 1529-1535.

Krol, A., P. Carbon, J.P. Ebel, and B. Appel. 1987. Xenopus tropicalis U6 snRNA genes transcribed by Pol III contain the upstream promoter elements used by Pol II dependent $U$ snRNA genes. Nucleic Acids Res. 15: 2463-2478.

Lerner, E.A., M.R. Lerner, C.A. Janeway Jr., and J.A. Steitz. 1981. Monoclonal antibodies to nucleic acid-containing cellular constituents: Probes for molecular biology and autoimmune disease. Proc. Natl. Acad. Sci. 78: 2737-2741.

Lührmann, R., B. Kastner, and M. Bach. 1990. Structure of spliceosomal snRNPs and their role in pre-mRNA splicing. Biochim. Biophys. Acta 1087: 265-292. 
Lund, E. and J.E. Dahlberg. 1989. In vitro synthesis of vertebrate U1 snRNA. EMBO $/$. 8: 287-292.

1992. Cyclic 2',3'-phosphates and nontemplated nucleotides at the 3 ' end of spliceosomal U6 small nuclear RNAs. Science 255: 327-330.

Lund, E. and P.L. Paine 1990. Nonaqueous isolation of transcriptionally active nuclei from Xenopus oocytes. Methods Enzymol. 181: 36-43.

Maniatis, T., E.F. Fritsch, and J. Sambrook. 1989. Molecular cloning: A laboratory manual, 2nd ed. Cold Spring Harbor Laboratory Press, Cold Spring Harbor, New York.

Maquat, L.E. 1991. Nuclear mRNA export. Curr. Opin. Cell Biol. 3: 1004-1012.

Mathews, M.B. and M. Francoeur. 1984. La antigen recognizes and binds to the 3 '-oligouridylate tail of a small RNA. Mol. Cell. Biol. 4: 1134-1140.

Mehlin, H., B. Daneholt, and U. Skoglund. 1992. Translocation of a specific premessenger ribonucleoprotein particle through the nuclear pore studied with electron microscope tomography. Cell 69: 605-613.

Michaud, N. and D. Goldfarb. 1992. Microinjected U snRNAs are imported to oocyte nuclei via the nuclear pore complex by three distinguishable targeting pathways. I. Cell. Biol. 116: $851-861$.

Munns, T.W., M.K. Liszewski, J.T. Tellam, H.F. Sims, and R.E. Rhoads. 1982. Antibody-nucleic acid complexes. Immunospecific retention of globin messenger ribonucleic acid with antibodies specific for 7-methylguanosine. Biochemistry 21: 2922-2928.

Neuman de Vegvar, H. and J.E. Dahlberg. 1990. Nucleocytoplasmic transport and processing of small nuclear RNA precursors. Mol. Cell. Biol. 10: 3365-3375.

Nigg, E.A., P.A. Baeuerle, and R. Lührmann. 1991. Nuclear import-export: In search of signals and mechanisms. Cell 66: $15-22$.

Ohno, M., N. Kataoka, and Y. Shimura. 1990. A nuclear cap binding protein from HeLa cells. Nucleic Acids Res. 18: 6989-6995.

Parry, H.D., D. Scherly, and I. Mattaj. 1989. "Snurpogenesis": The transcription and assembly of $U$ snRNP components. Trends Biochem. Sci. 14: 15-19.

Reddy, R. and R. Singh. 1992. Synthesis of small nuclear RNAs. Prog. Mol. Subcell. Biol. 12: 1-36.

Reddy, R., D. Henning, G. Das, M. Harless, and D. Wright. 1987. The capped U6 small nuclear RNA is transcribed by RNA polymerase III. I. Biol. Chem. 262: 75-81.

Rinke, J. and J.A. Steitz. 1982. Precursor molecules of both human 5S ribosomal RNA and transfer RNAs are bound by a cellular protein reactive with anti-La lupus antibodies. Cell 29: 149-159.

1985. Association of the lupus antigen La with a subset of U6 snRNA molecules. Nucleic Acids Res. 13: 2617-2629.

Singh, R., S. Gupta, and R. Reddy. 1990. Capping of mammalian U6 small nuclear RNA in vitro is directed by a conserved stem-loop and AUAUAC sequence: Conversion of a noncapped RNA into a capped RNA. Mol. Cell. Biol. 10: 939946.

Stefano, J. 1984. Purified Lupus antigen La recognizes an oligouridylate stretch common to the $3^{\prime}$ termini of RNA polymerase III transcripts. Cell 36: 145-154.

Steitz, J.A., D.B. Black, V. Gerke, K.A. Parker, A. Kramer, D. Frendewey, and W. Keller. 1988. Functions of the abundant U-snRNPs. In Structure and function of major and minor small nuclear ribonucleoprotein particles /ed. M.L. Birnstiel), pp. 115-154. Springer-Verlag, Heidelberg, Germany.

Sumpter, V., A. Kahrs, U. Fischer, U. Kornstadt, and R. Lühr- mann. 1992. In vitro reconstitution of $U 1$ and U2 snRNPs from isolated proteins and snRNA. Mol. Biol. Rep. 16: 229240.

Sun, J., D.P. Pilch, and W.F. Marzluff. 1992. The histone $3^{\prime}$ end is required for localization of histone mRNA to polyribosomes. Nucleic Acids Res. 20: 6057-6066.

Tazi, J., T. Forne, P. Jeanteur, G. Cathals, and C. Brunel. 1993. Mammalian U6 small nuclear RNA undergoes $3^{\prime}$ end modifications within the spliceosome. Mol. Cell. Biol. 13: 16411650.

Terns, M.P., E. Lund, and J.E. Dahlberg. 1992. 3'-end dependent formation of $\mathrm{U} 6$ small nuclear ribonucleoprotein particles in Xenopus laevis oocyte nuclei. Mol. Cell. Biol. 12: 30323040.

1993. A pre-export Ul snRNP in Xenopus laevis oocyte nuclei. Nucleic Acids Res. 21: 4569-4573.

Vankan, P., C. McGuigan, and I.W. Mattaj. 1990. Domains of U4 and U6 snRNAs required for snRNP assembly and splicing complementation in Xenopus oocytes. EMBO I. 9: 33973404.

Yang, H., M.L. Moss, E. Lund, and J.E. Dahlberg. 1992. Nuclear processing of the 3 '-terminal nucleotides of pre-Ul RNA in Xenopus laevis oocytes. Mol. Cell. Biol. 12: 1553-1560.

Zasloff, M. 1983. tRNA transport from the nucleus in a eukaryotic cell: Carrier-mediated translocation process. Proc. Natl. Acad. Sci. 80: 6436-6440. 


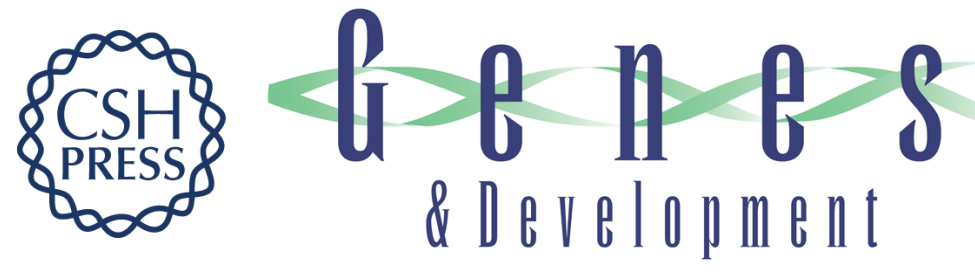

\section{Multiple cis-acting signals for export of pre-U1 snRNA from the nucleus.}

M P Terns, J E Dahlberg and E Lund

Genes Dev. 1993, 7:

Access the most recent version at doi:10.1101/gad.7.10.1898

References This article cites 51 articles, 21 of which can be accessed free at:

http://genesdev.cshlp.org/content/7/10/1898.full.html\#ref-list-1

License

Email Alerting

Service

Receive free email alerts when new articles cite this article - sign up in the box at the top right corner of the article or click here.

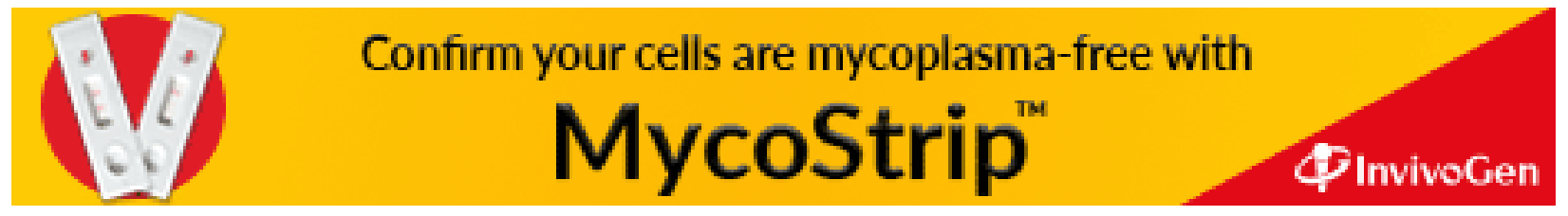

